\title{
Rethinking the Role of Escuelas Nuevas and Social Capital in Colombia Through the Lens of Peace-Building and Reconciliation
}

\author{
Debora Upegui-Hernàndez \\ The Graduate Center, City University of New York, United States of America
}

\begin{abstract}
The World Bank and the International Monetary Fund (IMF) endorse social capital to solve poverty and inequality. Colombia proposes urban school reform (Escuelas Nuevas) to increase its social capital. Social capital is accepted by 'indigenous researchers' without considering its societal and political context. The psychology of Martín Baró and Freire' de-ideologises such social capital concepts. Interviews with individual teachers, community members, and focus groups of elementary school parents and students were analysed for the consequences of Escuelas Nuevas for social capital, and for peace-building and reconciliation of violent conflict. Social capital did not stand in place of social justice programmes. Using social capital to redirect efforts against social inequalities constitutes 'structural violence' perpetuating the colonisation of indigenous communities.
\end{abstract}

We [psychologists] search for peace through interpersonal harmony. We avoid social strain and remain insensitive to power inequalities. And as long as we pursue harmony and avoid strain, we may remain disconnected from a majority of the world's populations that bear the yoke of structural inequalities. (Montiel, 2000, p. 294)

This opening quote characterises much of what has been the approach of psychology's intellectual work: as historical, de-contextualised and 'objective. Martín-Baró (1994) called on us to respond to different ethical standards in his theorising of liberation psychology. It was his belief that if we are to contribute to the liberation of our communities, we should use psychological theory to contribute to the process of de-ideologising the takenfor-granted assumptions behind our reality. This article represents an effort to contribute to make explicit the assumptions underlying the increasing efforts of international aid agencies to promote and require countries to develop programs that will increase their social capital. In doing so, I hope to contribute to the process of decolonisation (Smith, 2002) of Colombia, Latin America and the South Pacific Rim nations.

This article draws on research I conducted in Colombia in 2002 using individual interviews with teachers and community members, focus groups with parents of 3 rd and 5th grade students, and group interviews with $3 \mathrm{rd}$ and 5 th graders (UpeguiHernàndez, 2004). These were done within the context of participant observation in one urban school/community that recently adopted the Escuela Nueva methodology in Medellín, Colombia. My research examined the relationship between the community and the school and its consequences for social capital. This article focuses on the implications of that research for rethinking the role of Escuelas Nuevas and social capital in the processes of peace-building and reconciliation in communities that are in the midst of violent conflict. It concludes that although the existence of social capital in a community is important, it should not stand in the place of state and international programs for social justice. Using social capital to detract and redirect efforts to engage social inequalities constitutes 'structural violence' and perpetuates the colonisation of indigenous communities. 'Knowledge and culture [are] as much part of imperialism as raw materials and military strength ... it [is] undeniable also about power and domination' (Smith, 2002, p. 58). Ever since early colonial times, superiority over knowledge, language and culture was induced through colonial education. As 'indigenous researchers' begin to use the language of social capital, we need to frame it within its larger social and political context. 
In an attempt to contextualise and take a critical look at social capital theory, this article begins by presenting a brief political and economic overview of Colombia during the 19th century and early 20th century. Next, a discussion of contemporary political and economic issues facing the country and its place within the international arena, such as a changing international market for coffee exports, illicit drug-trade and military expansion traces some patterns and events in Colombia that have contributed to what Christie (2005) has called 'structural violence'. I then introduce the concept of social capital and present a discussion of its importance for education and why it is being used in Colombia by psychologists, educators and politicians alike. Fourth, I suggest that educational reform has played a role in maintaining imperial arrangements in Latin America, specifically in Colombia, contributing to structural violence. International and national promoters of globalised educational reforms become accomplices to such structural violence by avoiding the recognition and engagement of existing unjust and unequal conditions, in an effort to export knowledge and generalise results. I also highlight how these arrangements get perpetuated in the use of social capital discourse to promote the current Escuela Nueva reform efforts at the national level to comply with international aid agencies. I then present an overview of the history of the Escuela Nueva school reform. Finally, I argue that the perpetuation of imperial arrangements (economical, political and ideological) constitutes 'structural violence' against the people of Colombia and that any attempt to create and maintain peace ('structural peace-building') should think through the implications of using western-derived/imperialist concepts, such as social capital, as a globalised prescription for solutions to 'sovereignty struggles [that] came of age in real places, within fierce, place-based struggles for language, dignity, autonomy and lands under siege' (Fine, Tuck, \& Zeller-Berkman, in press, p. 34) and in doing so, contributes to 'structural violence' by maintaining imperial and socially unjust conditions.

\section{A Brief History of 'Post-Colonial' Colombia}

The political, economic and socially unjust conditions observable in contemporary Colombian society are deeply rooted in and linger from its history of material, economic and ideological colonisation by Europe and subsequently the United States (US). Since its discovery and colonisation by Spain, Colombia along with its neighbouring countries of Venezuela, Peru, Ecuador and Panama, have been at the mercy of world markets controlled by its colonisers. Formal independence in the 1800 s achieved little in bringing economic self-sufficiency (a pre-requisite for sustainable development) to Colombia and Latin America, perpetuating colonial economic relationships with the usual suspects (Great Britain, France, the US and Germany among others). As Safford and Palacios conclude, 'Civil wars tended to break out, or to be prolonged, in regions that were most deeply affected by the loss of demand for their products in foreign markets' (2002, p. 253). According to them, there were at least three civil wars in Colombia between 1876-1902 that could be attributed to conditions created by the changes in world markets of the times including La Guerra de los Mil Dias (The War of Thousand Days), when Panama, under the protection the US, left La Gran Colombia in 1903. Therefore, the pattern of economic, political and social inequality and injustices has been tied to structural violence and subsequent armed conflicts.

Between 1903 and 1945, Colombia's main export became its coffee, which gave this period the name 'The Republic of Coffee' in Colombian history. Colombia's reliance on the export of coffee reinforced a relationship of dependency on the US since its early beginnings as an independent (not sovereign) nation. 'If coffee gave life to Colombia's modern economy, the US was its umbilical cord' (Safford \& Palacios, 2002, p. 271), given that it was the main consumer of Colombian goods. In turn, the US pressured Colombia into becoming a main importer of US goods. Despite this unequal relationship, revenues from coffee exports provided the basis for the development of the transportation and communication systems in Colombia, as well as allowing for investment and acquisition of international credit. The coffee market has always been under the influence of international forces (Brazil, US, the global market, and so on). In response, the Colombian government established La Federación de Cafeteros (the Federation of coffee growers), which, 'played a positive role in many coffee areas, constructing aqueducts, schools [mostly Escuelas Nuevas], and roads - a source of much of its social legitimacy' (Safford \& Palacios, 2002, p. 271).

During this period, the US continued to intervene in Colombian economy and politics to secure its interests and imperialist project. For example, the US attempted to block the creation of La Flota Mercante Gran Colombiana to maintain its monopoly of sea transportation. By 1928, the US controlled every aspect of production, transportation and marketing of the banana production in Colombia under the United Fruit Company. This was an imperialist enclave of US citizens and companies that controlled banana growing territory in Colombia as if it was US soil. In 1928, the United Fruit Company and the Colombian military were protagonists of a massive massacre of strikers unhappy with their current exploitation. Once again, 'structural violence' in the form of economic and political exploitation results in 'episodic violence' to use Christie's language (2006). Such economic and political colonisation spread through Central America and there it was followed by episodes of violence and war as well. This is usually remembered as the period of the 'Banana Republics', a pejorative term used to describe 'a country whose 
government is primarily concerned with economics benefiting a colonial or corporate power, rather than values of democracy and social welfare' (Mithra, 2006).

Contemporary Political Economy: Coffee, Drugs and Military Support

The imperialist relationship between the US and Colombia continues into the 21 st century through among other, the controversial Plan Colombia and the Tratado de Libre Comercio (TLC- Free trade agreement). Despite enormous protest by Colombian constituencies (indigenous groups, labor unions, peasants, etc.), Colombian president Alvaro Uribe signed the agreement on February 2006 (Correa, 2005; 'Mujeres de 28 Municipios', 2005; 'Presidente Uribe pide', 2006; 'Universitarios Colombianos,' 2006). President George W. Bush and the US Government continued to pressure Colombia by threatening to withdraw funds from Plan Colombia if the TLC was not signed. Back in 2000, Clinton approved 1.3 billion dollars to launch the 2000-2005 Plan Colombia. According to a report by Viellete (2005), the Andean Counterdrug Iniaciative (ACI), Foreign Military Financing Program (FMF) and the US Department of State had contributed 4.5 billion dollars towards Plan Colombia. Despite much protest in Colombia and the US against Plan Colombia, President George W. Bush and the US Congress approved a budget of \$742 million for 2006 and \$721 million for 2007.

Escalating the patterns of structural violence and political and economic imperialist interests, the US has steadily increased its focus on military aid and presence in Colombian territory. Consistently $80 \%$ of the Plan Colombia's money has been designated for military spending. In a 2004 report for Congress, Tarnoff and Nowels estimated that approximately $87 \%$ of military aid will be used to buy military equipment from US industries. As the military escalates, so have the human rights abuses and massacres without any real results either in the reduction of violence or the reduction of cocaine growing and trafficking (Haugaard, Isacson, \& Stanton, 2005). In 2004, Colombia was the fifth largest recipient of US foreign aid ( $\$ .57$ billion) after Iraq ( $\$ 18.44$ billion), Israel ( $\$ 2.52$ billion), Egypt ( $\$ 1.87$ billion) and Afganistan ( $\$ 1.77$ billion), followed closely by Jordan ( $\$ .56$ billion). In Latin America, only two other countries receive substantial amounts of aid from the US as part of the ACI: Perú (.17\% billion) and Bolivia ( $\$ .15$ billion; Tarnoff \& Nowels, 2004).

Report after report demonstrates that military aid has done little to reduce drug trafficking. It has, however, contributed to the rise of human rights violations perpetrated by Colombian military forces and paramilitary groups. Both guerrilla and paramilitary groups have been opposed to the intervention of the US, and this intervention has only provoked violent retaliation from these groups. 'Recent [and past] history demonstrates convincingly that there is no military solution to the violence [crisis in Colombia]. There are too many actors, state authority is too weak, political and social demands are too great, historical resentments too high, and the violence is too rooted among political actors and communities' (Chernick, 1999).

The long spiral of violence that corrodes Colombian society today has its origins back in the 1940s and the 1950s when a civil war, better known as La Violencia, between Liberals and Conservatives (the two main political parties) ended the lives of an estimated 200,000 (Ceballos \& Martin, 2001; Roldan, 2002). Most of the violence occurred in the rural areas and being a member of one or the other party was reason enough to lose one's life. During the 1960s and 1970s, the violence and deaths by homicide were the result of small guerrilla insurgencies, common crime, post-Violencia political vendettas, local death squads and rural frontier violence. Parallel to this, the Colombian population grew enormously from about 12 million in 1951 to about 42 million in 2001 (Ceballos \& Martin, 2001). During the 1980 's and the 1990's, due to an unprecedented growth in the illegal drug economy and the increasing guerrilla activity, the violence levels rapidly increased both in the cities and in the rural areas. For the first time, the violence was beginning to touch the life of people in the urban cities. In prior decades, the violence had mostly restricted itself to rural areas. Urban militias controlled by guerrilla groups and hit squads financed by the drug cartels, terrorised the cities through bombs, kidnappings, homicides and bribery. Safford and Palacios (2002) pointed out that sadly one of the main causes of death among men between 16-34 years old in the three largest cities of Colombia (Bogotá, Medellín, and Cali) was homicide.

\section{Social Capital in an Educational Setting}

In 1991, Colombia embarked in a process of participatory democratic reform through the drafting of a new constitution where ideally all sections of civil society would participate (Ceballos \& Martin, 2001; Chernick, 1999; Sudarsky, 1999). This created an enormous amount of interest in social capital and ways to encourage and facilitate citizen participation and the development of civil society. On February 20, 2002, efforts to end the civil war in Colombia through peace talks ended abruptly. The civil war has affected disproportionately the rural areas of Colombia displacing millions of people from their homes and forcing them to move to the cities. 'An estimated 2.45 million Colombians were internally displaced at the end of 2001, including about 342,000 who became displaced during the year' (US Committee for Refugees, 2002). These displacements occur mainly in rural areas. Many of these displaced campesinos find themselves settling in the comunas (shantytowns), some of the poorest and most violent neighbourhoods on the outskirts of the cities. 
Social capital, according to James Coleman (1990, p. 302 ) is, 'unlike other forms of capital, social capital inheres in the structure of relations between persons and among persons'. Robert Putnam (1995, p. 67) furthers this definition by saying that social capital includes, 'features of social organisation, such as networks, norms, and social trust, that facilitate coordination and cooperation for mutual benefit'. Therefore, it 'refers to the set of resources that inhere in relationships of trust and cooperation between people' (Warren, Thompson \& Saegert, 2001, p. 1). Social Capital is a variable that operates at the community level since it is, 'a collective asset, a feature of communities, rather than the property of individuals' (Warren, Thompson \& Saegert, 2001, p. 1).

Schools play an important role in the development of social capital among communities. Testimony to this effect has been presented already by a number of researchers (Coleman, 1988; Croninger \& Lee, 2001; Khane, et al., 2001; Noguera, 2001; Sampson, 2001; Umphrey, 2001; Warren, et al., 2001). Coleman's work has demonstrated how schools may or may not represent resources of social capital for students, parents and communities. Already in the 1970's, Loury defined social capital as the 'relationships, shared values, and social trust that help people act together for their mutual benefit' (quoted by Umphrey, 2001, p. 3). Therefore, the importance of social capital resides in its potential to facilitate social action and social change.

A recent book published by the World Bank, Colombia: Essays on conflict, peace and development (Moser, 2000) illustrates the recent emphasis placed by the World Bank development projects on social capital as a key element to ending poverty and creating sustainable peace by bringing about social, economic and political development. Its analysis of the armed conflict in Colombia was reduced to assessing its costs in terms of capital, be it physical, human, social or natural, leaving out any real discussion of underlying conflicts and inequalities among Colombian society. In this volume, Moser (2000) argues that violence in Colombia reduces its amount of human, physical, economic, social and natural capital, and therefore stagnates the development of the nation. Morse quotes Putnam's research and his findings that social capital affects the efficiency and sustainability of development processes.

There are increasing worries that 'democracy' (the landmark of western thought accomplishments and the basis of the US dominant ideological discourse) may be undermined by the escalating violence and its effect on social capital. It is not a coincidence, then, that it is precisely at this moment that Escuelas Nuevas re-emerges in the Colombian national education discourse. The Escuela Nueva is definitely a great education model with excellent results, but it can not be denied that its promoters have begun to market it under the rubric of its social capital building potential, effectively giving international aid agencies a product that can be exportable. In previous decades, Escuelas Nuevas had been highlighted for its cost effectiveness and improved academic scores of rural students over urban students.

There have been attempts to measure social capital in Colombia as a tool to reduce violence (Rodriguez, Grant, \& Harphan, 2000) and the South Bank University of London; the Municipal Department of Health (Calí, Colombia) and the Consulting Foundation for Health Programmes (FUNDAPS, Calí, Colombia). Another study by Forero Pineda (2002) of the Universidad Nacional de Colombia surveyed a number of communities to measure their social capital through a quantitative analysis. Forero Pineda's study compares rural communities that have Escuelas Nuevas and rural communities that have traditional schools. It, however, limits itself to establishing a correlation between the existence of Escuelas Nuevas (or not), and the level of social capital of the community. Preliminary findings of his study suggest a positive relationship between Escuelas Nuevas and social capital. Yet it is not understood how the Escuelas Nuevas model and its curriculum foster social capital in the community and their children. Therefore, there is a need for qualitative research to understand the relationship between the democratic and community aspects of Escuelas Nuevas and the improvement of social capital.

The Colombian Government has made explicit commitments to promote social capital as a way to strengthen institutions, and support social development and peace (Echeverry, 2000). Researchers have previously demonstrated that having social capital in a community can reduce crime, improve neighbourhood conditions and safety (Sampson, 2001), improve school success (Coleman, 1988; Noguera, 2001), reduce dropout behaviour (Croninger \& Lee, 2001) and improve economic prosperity (Gittell \& Thompson, 2001; Putnam, 1995). However, social capital theory has recently become a contended issue and it has been questioned by researchers (Boggs, 2002; Smith \& Kulynych, 2002 ). It has been criticised for its lack of discussion of gender roles, race, class, and power hierarchies; and for overestimating the power that social networks have in the absence of material and economical resources. These studies also warn against the eagerness of nation-states to leave at the hands of its people the responsibility for developing their communities and eliminating more drastic and much needed measures to addressed economic, social and political inequalities.

\section{Educational Reform: a Legacy of Development Projects}

After WWII, the concept of 'development projects' entered the international arena and became a priority for nation-states (McMichael, 1996). It linked human development and economic growth. Smith (2002) implies that development is more than a set of economic, political and military policies. In fact, attached to 
the concept is an ideology that divides the world into 'developed' and 'underdeveloped' countries, which becomes analogous to colonial terms like 'civilised' and 'uncivilised' (also 'North' vs. 'South'). This ideology holds western civilisation as the model and sets the ground for the justification of imperialist projects of the 'North'. Education becomes an essential aspect of the development project in so far as it becomes a tool for imposing and spreading new western scientific knowledge, producing good/skilled workers and developing new local elites that become allies in the imperialist project (McMichael, 1996; Smith, 2002).

This emphasis on human development can still be appreciated in the 21st century simply by browsing the websites of international aid organisations and nongovernmental agencies focused on issues of development, such as the World Bank, the International Monetary Fund (IMF), United States Agency for International Development (USAID) and the United Nations (UN) among others. According to the World Bank's website, about $9 \%$ of its budget went to fund projects related to education. In 2005, Education was the fifth area of investment for the World Bank after Health/Social Services, Law and Justice/Public Administration and Transportation and Water, Sanitation and Flood Protection (World Bank Group Brochure, 2006). These organisations are generally controlled by countries that make up the 'developed' world, perpetuating their imperialist efforts. The domination of masses by elites is rooted not only in the polarisation of control over the means of material production but also over the means of knowledge production, including ... the social power to determine what is valid or useful knowledge' (Rahman, 1985; paraphrased by Fine, Thompson, \& Saegert, in press, p. 6). It is not surprising then, that educational reforms and innovations in Latin America are funded by grants from some of these international agencies, occasionally with matching funds from the affected countries. The Escuelas Nuevas model is not an exemption. Ironically, Latin American countries' ability to fund their own educational programs is further restricted by international credit agencies such as IMF and World Bank that frown upon expanding public spending, including education.

Another example of how these international aid agencies shaped educational reform in Colombia was the case of the 'rural university' founded by the Foundation for the Application and Teaching of Sciences (FUNDAEC, Calí). It was founded in 1974 with funds from the Rockefeller foundation as a bottom-up approach that challenged standard notions of development. Later in the 1980s it was funded by USAID, which focused on programmatic aspects they felt could be 'exported' to other 'third world countries' such as the 'System of Tutorial Learning' (SAT by its English acronym). A rich experience of community building and knowledge production was distilled into a discrete/decontextualised method of teaching, stripping off all traces of local context, knowledge and history that were embedded in its development. Its attractiveness to the international aid agencies such as the World Bank rested especially in its potential for exportation to other Latin American countries (Richards, 1999), as is the case of the Escuela Nueva. Despite being forced to accommodate USAID's goals, the rural university has managed to develop parallel programs that build the intellectual capacity of campesinos and use their academic knowledge in improving their lives and farms. The USAID's approach to the project was that by focusing on educating rural populations, they could reduce the number of illiterate citizens migrating to the cities looking for jobs once harvesting agriculture produce was no longer profitable, due to low prices in the global market. In other words, this was a mechanism to maintain the unequal and exploitative relationships that fuel global markets and economies while preventing further disruption of the social and economic system due to the consequences of such economic exploitation.

\section{Urban Escuela Nueva}

In the last few years, the Colombian government has been considering the implementation of the Escuelas Nuevas model in their urban public schools at the national level. In January 2000, a small number of schools were selected to test out the model in an urban context. Seven elementary schools in the city of Bogotá (the country's capital) and three schools in the city of Medellín (the second largest city of Colombia) were identified and committed themselves to adopting the Escuela Nueva model. They were provided with closed training for the first year (2000-2001) and one additional year of technical support (2001-2002). They also received the learning materials and self-learning guides needed by the students.

This expansion to the urban schools in Colombia was in part fuelled by the World Bank's selection of Escuelas Nuevas as one the three most successful local initiatives in 'third world countries' that has succeeded implementation at the national level in 1988-1989. The United Nations 2000 Human Development Report highlights the Escuela Nueva reform as one of the most important achievement of the country. In doing so, they have promoted its 'exportation' to a number of so-called 'third world countries' such as Dominican Republic, Brazil, Guatemala, Honduras, Mexico, Costa Rica, Ecuador, Perú, Bolivia, Paraguay, Panamá, Nicaragua, Argentina, and Chile (Colbert, 2000) where apparently they have been emulated successfully.

However, this approach should be specially questioned, if we consider that this bottom-up school reform is being transplanted to other countries as a top-down school reform. Some researchers have questioned the success of bringing this local school reform to the 
National Level (Colbert, 2000; Leggett, 2003). Additional research should investigate to what extent the principles of communities' ownership of how these schools take shape, can remain after its 'exportation' to such different places. It can not be assumed that simply being a 'third world country' will enable this transplantation. The research available on Escuelas Nuevas has documented their achievements in the academic level of students, the training of teachers and the economic viability of the reform, but it has not yet explored to any great extent the effects of their democratic aspects, participatory emphasis and innovative curriculum, on the children and their communities.

The Escuela Nueva model was created in 1976, as a bottom-up approach to school reform where each community had a role in shaping what the schools looked like in their communities (Drabble, 1999). They represented an attempt to rescue UNESCO's failed efforts in introducing the Unitary Schools reform in 1975. The isolation and small size of these rural communities afforded them a lot of autonomy in their decisions about how to organise their schools and make the best use of the methodology. Unfortunately, the Escuela Nueva model is being implemented in urban schools at the national level using a top-down approach that lacks local input and is subject to pressures of standardised testing and violence. As a result, the connection between the methodology, its curriculum and the community is being sacrificed in order to obtain better academic results at the national level. The students in urban Escuelas Nuevas are doing better academically by improving the social capital within the schools. Yet, the urban Escuelas Nuevas are avoiding any real work that would improve the social capital of their students' communities, which would in the end produce even greater academic and social gains for their students, as well as, their communities, and in the process contribute to structural peace-building within their society.

These findings have implications for understanding the different ways in which urban Escuelas Nuevas can have an impact on social capital. In rural settings, teachers were committed to building social capital through their close relationship to the community. Once they were transferred to urban settings, these same teachers decided to concentrate their efforts on building the social capital inside the school through their relationship with the children, other teachers and the director. They felt alienated and powerless with respect to the community outside the school. Therefore, the Urban Escuela Nueva needs to decide whether to concentrate their efforts in building social capital inside the school alone, or to seriously look for ways to bridge the greater gap between school and community in urban settings. They have co-opted the teaching method, but have stripped off from it those aspects that require deep and rich work with the community. They have failed to move outside of the safe boundaries of their school and to erode the existing socially unjust hierarchical relationship between teachers and parents, class differences, and inequalities in the access to education and to other social goods. Sadly, these urban Escuelas Nuevas have become 'accomplices, abetters, exploiters, romanticisers, pacifiers, assimilators, includers, forgetters, and democratisers' (Fine et al., in press, p. 5). They have colluded and collaborated in this process of colonisation by maintaining the social order as it was. In the process, they have become another element that adds to the structural violence perpetrated by the international aid agencies, globalised economic and political powers, and the local elites.

\section{Looking towards the Future: Implications for Peace-Building and Reconciliation}

This article should be situated within the larger social, political and economical context of globalisation and global politics of today. One of the major social injustices that Colombians have been faced with for the last five decades is the reality of civil war, despite president Uribe's continuous official denial of the existence of an armed conflict (Mutchler, 2005). Day after day, millions of children, youth and adults suffer the consequences of being the innocent victims of an armed conflict that is largely out of their hands. Living in fear, having their freedom curtailed, mourning for those who fall victims to the conflict and having to use all of their energies to keep hope alive for handing down to their children a Colombia in peace, are just a few of the everyday injustices and episodes of violence that constitute Colombian everyday life.

Colombians understand that peace is not easy to achieve and that it requires a deep commitment to reevaluating their social values, knowledge and social inequalities that initiated the conflict many years ago, and continues to fuel it. At the same time, they understand that promoting a culture of peace involves a process of national (and transnational) social development in which all national (and transnational) constituencies learn how to be part of a community of peace. This is not always easy. Colombians are embarking in this process while they, as a country, are themselves victims of social inequality and social injustices at the nation-state level in our globalised world market. It is the international market and policies about the 'war on drugs' like Plan Colombia and post-9/11 'war on terrorism' that continue to fuel many of the country's inequalities, as well as, its armed groups.

This is a process and a conversation that should be held at a transnational, international and global level as well. It sits in the midst of global social injustices and the need for global and just social development. Organizations like the International Monetary Fund (IMF), and the World Bank, which ironically are the main pushers of a 'social capital' discourse that restrains 
so called 'third world countries' abilities to invest in reducing their social inequalities and instead emphasise their economic and social doom by pushing the adoption of continued economic exploitation through free trade agreements such as NAFTA, TLC, CAFTA, and neoliberal policies that have already proven to be catastrophic (i.e., the economic downfall of Argentina, Brazil, Ecuador in the late 1990s). These policies are generally opposed by the masses and supported by the elites.

That said, if the main purpose of peace-building is to create a 'stable social equilibrium in which the surfacing of new disputes does not escalate into violence and war' (Haugerudbraaten, 1998), a successful process of 'structural peace-building' involves not only repairing the problems at the root of the conflict, but also changing how the conflicting parties interact with each other (Maises, 2003). It is here where social capital and Escuelas Nuevas becomes important. Maises further explains that building peace involves reducing the effects of war-related hostility, by repairing and transforming damaged relationships. Peace-building centres on reconciliation, forgiveness, trust building, and future imagining; and minimises poor communication and maximises understanding.

Yet, at no point in time should these efforts constrain or replace what Christie (2006) calls 'structural peace-building.' 'Although violence can be prevented and mitigated with episodes of peace-building, an enduring peace will require structural changes, that is, the restructuring of political and economic systems in ways that promote the equitable and sustainable satisfaction of human needs' (Christie, 2006, p. 7). Unfortunately, it seems that the pre-requisites for 'structural peace-building' to occur, that is structural change, go against and contradict the actions and goals of the international political and economic globalised (imperialist/colonialist) powers, exerted through the work of aid agencies such USAID, IMF, the World Bank, and so on.

As 'indigenous researchers' begin to use the language of social capital, we need to frame it within its larger social and political context. Contemporary political and economic issues facing the country and its place within the international arena, such as a changing international market for coffee exports, illicit drugtrade and military expansion contribute to the 'structural violence' in Colombia. I have argued that educational reform has played a role in maintaining imperial arrangements in Latin America, specifically in Colombia by contributing to structural violence. International agencies, such as the IMF and the World Bank, and national promoters of globalised educational reform become accomplices to such structural violence by avoiding the recognition and engagement of existing unjust and unequal conditions, in an effort to export knowledge and generalise results. These patterns of 'structural violence' are perpetuated in the use of social capital discourse to promote the current Escuela Nueva reform efforts at the national level in order to comply with international aid agencies. Therefore, the perpetuation of imperial arrangements (economical, political and ideological) constitutes 'structural violence' against the people of Colombia and any attempt to create and maintain peace ('structural peace-building') should think through the implications of using western-derived/imperialist concepts, such as social capital, as a globalised prescription for solutions to local, culturally grounded, context specific struggles. Doing so, contributes to 'structural violence' by maintaining imperial and socially unjust arrangements. As Fine et al. (in press, p. 36) warn us, when ' $[\mathrm{t}]$ he stubborn particulars of local context, ... and struggle are disregarded, globalised justice research becomes another act of colonisation'.

It is not difficult to see how building social capital, based on relationships of trust and mutual understanding, is essential to a healthy process of peace-building. Social capital is definitely a key to creating a more peaceful society in which real social and political participation is possible. Escuelas Nuevas are in theory and through conscious and self-critical process, an ideal institution that could serve and nurture the existence of social capital. Yet, is it sound to devote so much of our efforts and time to it? Should we not be looking at other measures that will directly address the structural inequalities between the North and the South, between the poor and the elites? Social capital would most likely follow in a more just and less unequal society. This is why we should continue to be critical of development projects introduced by first world nations, international aid agencies and local elites. We need to re-think development and what it means from the point of view of the 'third world', the 'indigenous', the 'colonised' and redefine it. It is not an easy task, but it must be done. At every step we should examine the pros and cons of receiving support for our initiatives and educational reforms from international organisations. We should remain aware of the danger of becoming collaborators of imperialist projects. 'Inquiry that seeks to reveal the historic and contextual specificities of place and identity can shed light on the worldly effects of domination, and resistance.' (Fine et al., in press, p. 34)

\section{Acknowledgment}

The research project discussed in this article was funded by the Social Justice and Social Development in Educational Studies Fellowship (2002-2004) from the Spencer Foundation. I would like to thank Ethel Tobach, Michelle Fine, and the Society for the Study of Peace, Violence and Conflict, Division 48 of the American Psychological Association for making possible my 
participation in the 2004 Symposium on Pacific Rim Nations' Indigenous Psychology, which served as the basis for this article. My work on this article was made possible by the Center on Philanthropy and Civil Society Faculty/Student Seminar 2005-2006 on 'Justice, Citizenship, and Civil Society' at the Graduate School and University Center, The City University of New York.

\section{References}

Boggs, C. (2002). Social capital as political fantasy. In S.L. McLean, D. Schultz, \& M.B. Steger (Eds.), Social capital: Critical perspectives on community and "Bowling alone", (pp. 183-202). New York, NY: New York University Press.

Ceballos, M., \& Martin, G. (2001). Colombia: Between terror and reform. Unpublished manuscript. Retrieved March 3, 2006

from

http://www.georgetown.edu/sfs/programs/clas/Colombia/c olombia_program_publications.htm

Chernick, M. (1999, August). Changing perceptions of violence in Colombia and implications for policy. In C. Moser, \& S. Lister (Eds.), LCR Sustainable Development Working Paper N.5, Urban Peace Program Series: Violence and Social Capital. Proceedings of the LCSES Seminar Series, 1997-1998. The World Bank: Latin America and Caribbean Region, Environmentally and Socially Sustainable Development.

Chesterfield, R. (1994). Indicators of democratic behavior in Nueva Escuela Unitaria, NEU, schools (Basic Education Strengthening -BEST- Project). Guatemala: United States Agency for International Development [USAID].

Christie, D. (2006) What is peace psychology the psychology of? Journal of Social Issues, 62(1), 1-17.

Colbert, V. (2000a). Mejorar la calidad de la educación para el sector rural pobre: El caso de la Escuela Nueva en Colombia. In O.L. Acosta N., \& M.L. Henao V. (Eds.), Coyuntura Social, numero 22 Mayo, Colombia: Conciencias.

Coleman, J. (1988). Social capital in the creation of human capital. American Journal of Sociology, 94, pp. 95-120.

Coleman, J. (1990). Foundations of social theory. Cambridge, MA: Harvard University Press.

Correa, J. (2005, August 22). Sin consultar, el gobierno firmara el TLC. EL Tiempo. Retrieved March 13, 2006, from http://www.bilaterals.org/article.php3?id_article $=2554$

Croninger, R., \& Lee, V. (2001). Social capital and dropping out of high school: Benefits to at-risk students of teachers' support and guidance. Teachers College Record, 103(4), $548-581$.

Departamento Nacional de Planeación. (1997). La calidad de la educación y el logro de los planteles educativos. Planeación y Desarrollo (Vol. 28, 1, Marzo, pp. 25-51). Bogota, Colombia: Author.

Drabble, M. (1999). Escuela Nueva: Implementing educational change in developing countries. Unpublished manuscript, John F. Kennedy School of Government, Harvard University at Boston, $\mathrm{CN}$.
Echeverry, J.C. (2000, October). Consultative group in support of the peace process. Bogota, Colombia: Departamento de Planeación Nacional [DPN].

Fine, M; Tuck, E., \& Zeller-Berkman, S. (in press). Do you believe in Geneva? Methods and ethics at the global nexus. In N. Denizin, L. Smith, \& Y. Lincoln (Eds.), Critical and indigenous knowledges. Beverly Hills: Sage.

Forero Pineda, C. (2002, September). Escuela Nueva, Comportamiento Democrático y Convivencia. Paper presented at the II Encuentro Internacional y V Encuentro Nacional en Escuela, Familia y Medios de Comunicación, Escenarios para la Paz y el Desarrollo Humano, Manizales, Colombia.

Gittell, R., \& Thompson, P.J. (2001). Making social capital work: social capital and community economic development. In S. Saegert, J.P. Thompson, \& M.R. Warren (Eds), Social capital and poor communities (pp. 115-135). New York, NY: Russell Sage Foundation.

Greene, M. (1988). The dialectic of freedom. Teachers College Press: New York.

Haugaard, L., Isacson, A., \& Stanton, K. (2005, April) Propuesta para una nueva política hacia Colombia. Report prepared for the Latin America Working Group Education Fund (LAWG), the Center for International Policy (CIP), Washington Office on Latin America (WOLA), and the US Office on Colombia (USOC). Retrieved August 10, 2005 from http://www.wola.org/Colombia/colombia.htm

Haugerudbraaten, H. (1998) Peace building: Six dimensions and two concepts. African Security Review, 7, 6. Retrieved May 24, 2005 from http://www.iss.co.za/Pubs/ASR/ 7No6/Peacebuilding.html

Kahne, J., O’Brien, J., Brown, A., \& Quinn, T. (2001). Leveraging social capital and school improvement: The case of a school network and a comprehensive community initiative in Chicago. Educational Administration Quarterly, 37(4), 429-461.

Leggett, I. (2003). The Escuela Nueva of Colombia: Different perspectives on an example of primary education reform. Unpublished manuscript, Institute of Education, University of London, London. Retrieved March 13, 2006, from http://www.ioe.ac.uk/multigrade/escuela_nueva.htm

Maiese, M. (2003). What it means to build a lasting peace. The Beyond Intractability Knowledge Base Project, University of Colorado, Boulder, CO. Retrieved May 24, 2005 from http://www.beyondintractability.org/m/peacebuilding.jsp

Martín- Baró, I. (1994). Writings for a liberation psychology. Cambrige, MA: Harvard University Press.

McMichael, P. (1996). Development and social change: A global perspective. Thousand Oaks, CA: Pine Forge Press/Sage Publications.

Mithra, S. (2006). What is a Banana Republic? WiseGeek. Retrieved July 14, 2006 from http://www.wisegeek.com/ what-is-a-banana-republic.htm

Montiel, C. (2001). Toward a psychology of structural peacebuilding. In D. Christie, R. Wagner, \& D. Winter (Eds.), Peace, conflict, and violence: Peace psychology for the 21st century (pp. 287-294). Upper Saddle River, NJ: Prentice Hall. 
Moser, C. (2000). Violence in Colombia: Building sustainable peace and social capital. In A. Solimano (Ed.), Essays on conflict, peace and development (pp. 9-70). Washington, DC: The World Bank.

Mujeres de 29 Municipios del Magdalena medio protestaron contra el conflicto y el TLC. (2005, April 5). El Tiempo. Retrieved on March 13, 2006 from http:// eltiempo.terra.com.co/coar/DER_HUMANOS/derechoshu manos/ARTICULO-WEB-_NOTA_INTERIOR2028715.html

Mutchler, M. (2005, January 24). Colombia cannot deny internal arms conflict. Report prepared for Refugees Internaitonal. Retrieved October 10, 2007, from http://www.interaction.org/newswire/detail.php?id=3649.

Noguera, P.A. (2001). Transforming urban schools through investments in social capital. In S. Saegert, J.P. Thompson, \& M.R. Warren (Eds.), Social capital and poor communities (pp.189-212). New York: Russell Sage Foundation.

Presidente Uribe pide pensar en grande en el TLC y anuncia ayuda al campo. (2006, February 28). El Tiempo. Retrieved March 13, 2006 from http://eltiempo.terra.com.co/ economia/2006-02-28/ARTICULO-WEB-_NOTA_ INTERIOR-2766205.html

Psacharopoulos, G., Rojas, C., \& Vélez, E. (1992). Achievement evaluation of Colombia's Escuela Nueva: Is multi-grade the answer? (Policy Research Working Paper, WPS 896). Washington, DC: The World Bank.

Putnam, R. (1995). Bowling alone: America's declining social capital. Journal of Democracy, 6, 65-78.

Richards, Michael (1999). Applying Baha'i social and economical development principles to rural education and development in Latin America. Paper presented at the 3rd Conference of International Environment Forum, August 15-18, Sidcot, United Kingdom.

Rodriguez, C., Grant, E., \& Harpham, T. (2000, June). Collaboration between concerted actions: a proposal on social capital, youth violence and mental health. Paper presented at the 'Health and Human Settlements in Latin America' conference, South Bank University, London.

Roldán, M. (2002). Blood and fire: La violencia in Antioquia, Colombia, 1946-1953. London: Duke University.

Safford, F., \& Palacios, M. (2002). Colombia: fragmented land, Divided society. New York: Oxford University Press.

Sampson, R.J. (2001). Crime and public safety: Insights from community-level perspectives on social capital. In S. Saegert, J.P. Thompson, \& M.R. Warren (Eds.), Social capital and poor communities (pp.89-114). New York: Russell Sage Foundation.

Smith, L.T. (2002). Decolonizing methodologies: Research and indigenous peoples. London: Zed Books.
Smith, S.S., \& Kulynych, J. (2002). Liberty, Equality, and ... Social Capital? In S.L. McLean, D. Schultz, \& M.B. Steger (Eds.), Social capital: critical perspectives on community and "Bowling alone" (pp. 127-146). New York: New York University Press.

Social capital and the world bank (2002). Poverty net, The World Bank Group and Michigan State University. Retrieved on March 13, 2006 from http://www1. worldbank.org/prem/poverty/scapital/bank1.htm

Sudarsky, J. (1999). Colombia's social capital: The national measurement with the BARCAS. Bogota, Colombia: Departamento Nacional de Planeación [DNP]. Retrieved March 3, 2006, from http://www.worldbank.org/ poverty/scapital/library/sudarsky.htm

Tarnoff, C., \& Nowels, L. (2004, April 15). U.S. foreign aid report: An introductory overview of U.S. programs and policy. Washington, DC: Congress Research Services, The Library of Congress. Retrieved February 25, 2006 from http://www.usinfo.state.gov/usa/infousa/trade/files/98916.pdf

Umphrey, M. (2001). Sowing clover: Schools, communities, and social capital. Heritage Bulletin, 1(1), 9 pages. Retrieved March 3, 2006 from http://www.edheritage.org/ articles/socapital2.htm

Universitarios colombianos protestan por el TLC. (2006, February 27). Prensa Latina, [electronic version]. Retrieved on March 13, 2006 from http://www.prensalatina. com.mx/article.asp?ID=\%7BDE1F8D0E-0CF0-4D14ADD2-D7B445366B2C\%7D

Upegui-Hernàndez, D. (2004). (Re)populating and (Re)contextualizing social capital theory: A life sketch of an Escuela Nueva teacher in Colombia. Unpublished master's thesis, The Graduate Center, City University of New York. United States of America.

US committee on refugees (2002). Country Report for Colombia. Washington, DC. Retrieved March 13, 2006, from http:// www.refugees.org

Veillette, C. (2005, April 9). Plan Colombia: A progress report. Washington, DC: Congress Research Services, The Library of Congress. Retrieved February 25, 2006 from http://www.ndu.edu/library/docs/crs/crs_rl32774_ 09may05.pdf

Warren, M.R., Thompson, J.P., \& Saegert, S. (2001). The role of social capital in combating poverty. In S. Saegert, J.P. Thompson, \& M.R. Warren (Eds.), Social capital and poor communities (pp. 1-28). New York: Russell Sage Foundation.

World Bank Group Brochure (2006). Working for a world free of poverty. The World Bank, Washington, DD. Retrieved March 13, 2006 from http://siteresources.worldbank.org/ EXTABOUTUS/Resources/wbgroupbrochure-en.pdf 